Dicle Tıp Dergisi / Dicle Med J (2018) 45 (1) : 77 - 84

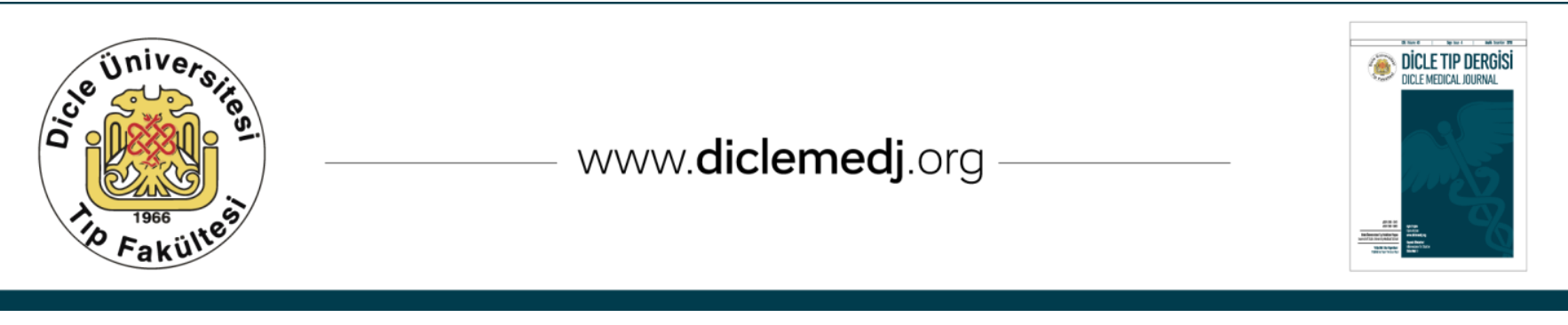

Original Article / Özgün Araştırma

\title{
The fatigue perception and its role in patient management
}

\author{
Ceyhun Yurtsever ${ }^{1}$, Turan Set ${ }^{2}$, Elif Ateș ${ }^{3}$ \\ 1 Karadeniz Technical University, Faculty of Medicine, Department of Family Medicine, Trabzon, Turkey ORCID: 0000-0003-4889-9919 \\ 2 Karadeniz Technical University, Faculty of Medicine, Department of Family Medicine, Trabzon, Turkey ORCID: 0000-0001-5931-0861 \\ 3 Karadeniz Technical University, Faculty of Medicine, Department of Family Medicine ORCID: 0000-0003-3805-7144
}

Received: 13.12.2017; Revised: 16.02.2018; Accepted: 21.02.2018

\begin{abstract}
Objective: Fatigue is one of the most common complaints in primary care. Patients' fatigue perceptions may be very different from each other. We aimed to determine the fatigue perception and its relationship with fatigue severity, sociodemographic characteristics, history, physical examination and laboratory findings in patients with complaints of fatigue.

Methods: This study was carried out as a cross-sectional study in a tertiary family medicine clinic between June 2016 and June 2017. All patients aged 18 years and over who were complaining of fatigue for at least 1 month were invited to study. Fatigue perceptions of volunteers who agreed to participate in the study $(n=116)$ were evaluated with a structured form prepared by researchers. Fatigue severity was measured using Fatigue Severity Scale and Checklist Individual Strength surveys. Patients' records including history, physical examination and laboratory results were included in the study.

Results: The mean age of participants was $29.5 \pm 9.8$ years and $87.9 \%$ were female. We asked patients "what do they mean by fatigue?" and "what fatigue complaints contain?". Tiredness, lack of energy and sleeplessness - somnolence desire to sleep were the most common answers. Expression that had the highest score from the fatigue severity scales was the needle hurt sensation for all body. In patients' records, the most common findings in patients with fatigue were vitamin D deficiency (84.5\%), sleeping problem (72.8\%) and depression (69\%). When the relationship between fatigue perceptions and possible etiologic factors was examined, it was observed that most of them were related with the depression risk. As a result, it was observed that seven different findings affected nineteen different fatigue perceptions.

Conclusion: In this study, fatigue perception has been shown to be as important as other features. The physicians should investigate its content and try to understand the patient.
\end{abstract}

Keywords: Depression, fatigue, perception, primary care, sleep

DOI: $10.5798 /$ dicletip. 407248

Yazıșma Adresi / Correspondence: Ceyhun Yurtsever, Karadeniz Technical University, Faculty of Medicine, Department of Family Medicine, Trabzon, Turkey e-mail: ceyhunyurtsever@hotmail.com 


\section{Halsizlik algısı ve hasta yönetimindeki rolü}

\section{Özet}

Amaç: Halsizlik birinci basamakta en sık karşılaşılan şikayetler arasındadır. Hastaların halsizlik algıları birbirinden çok farklı olabilmektedir. Bu çalışmada halsizlik şikayeti ile başvuran hastalarda halsizlik algısının ve bunun halsizlik şiddeti, sosyodemografik özellikler, öykü, fizik muayene ve laboratuvar bulgularıyla ilişkisinin belirlenmesi amaçlanmıştır.

Yöntemler: Bu çalışma Haziran 2016 - Haziran 2017 tarihleri arasında bir üniversite aile hekimliği polikliniğinde kesitsel bir araştırma olarak yürütüldü. En az 1 aydır olan halsizlik şikayeti ile başvuran 18 yaş ve üstündeki bütün hastalar çalışmaya davet edildi. Çalışmaya katılmayı kabul eden gönüllülerin $(n=116)$ halsizlik algıları araştırmacılar tarafından oluşturulmuş yapılandırılmış bir form kullanılarak değerlendirildi. Yorgunluk Şiddet Ölçeği ve Bireysel Dayanıklılık Kontrol Listesi kullanılarak halsizlik şiddeti ölçüldü. Öykü, fizik muayene ve laboratuvar bulgularını içeren poliklinik kayıtları da çalışmaya dahil edildi.

Bulgular: Katılımcıların yaş ortalaması 29,5 \pm 9,8 yıldı ve \%87,9'u kadındı. Hastaların halsizlik derken ne demek istedikleri ve halsizlik şikayetlerinin neleri içerdiği sorgulandığında en sık "yorgunluk", "enerji eksikliği" ve "uykusuzluk, uyku hali, uyuma isteği" cevaplarının verildiği görüldü. Halsizlik şiddet ölçeklerinden en yüksek puanı alan ifade her tarafına iğne batıyormuș hissiydi. Poliklinik kayıtları incelendiğinde halsizliği olan hastalarda en sık tespit edilen bulgular D vitamini eksikliği $(\% 84,5)$, uyku problemi $(\% 72,8)$ ve depresyon tarama pozitifliği (\%69) idi. Halsizlik algılarının olası etiyolojik faktörlerle ilişkisi incelendiğinde bunların çoğunluğunun depresyon riski ile ilişkili olduğu görüldü. Toplamda yedi farklı bulgunun on dokuz farklı halsizlik algısını etkilediği görüldü.

Sonuç: Bu çalıșmada, halsizlik algısının halsizliğin diğer özellikleri kadar önemli olduğu gösterilmiștir. Hekimlerin halsizlik içeriğini sorgulaması ve hastayı anlamaya çalışması hasta yönetimine katkı sağlayacaktır.

Anahtar kelimeler: Birinci basamak, depresyon, halsizlik, halsizlik algısı, uyku.

\section{INTRODUCTION}

Fatigue is the main symptom of $5-20 \%$ of patients in primary care $^{1-5}$ and is the cause of 10 million consultations per year6. It is a nonspecific symptom that is often associated with many physical and psychological disorders and a difficult mood to describe ${ }^{3,7}$. Patients can complain about it by naming very different situations as fatigue. It is possible to replicate samples such as lack of energy, lack of concentration, malaise, exhaustion, muscle weakness, somnolence ${ }^{8,9}$.

Fatigue disrupts daily function and work ability, reduces work performance and increases health expenditures ${ }^{10-}$ 14. Therefore, patients see fatigue as an important complaint. However, the fact that the complaint of fatigue is filled with diagnostic uncertainties, results in the failure of the physicians to pay due attention and there is inconsistency between the doctor and patient expectations ${ }^{3}$. Two thirds of the patients are not satisfied with the quality of medical care received ${ }^{15}$.

Early and effective management at primary care can prevent the chronicity of fatigue ${ }^{3}$. This will prevent the social and occupational life of the patients from being negatively affected and job continuity and efficiency from falling in the long run. In this respect, better understanding of the patients' fatigue perception and identification of factors that may be associated with fatigue will provide significant contributions to patient management.

In this study, we aimed to determine the fatigue perception and its relationship with fatigue severity, sociodemographic characteristics, history, physical examination and laboratory findings in patients with complaints of fatigue.

\section{METHODS}

This study was carried out as a cross-sectional study between June 2016 and June 2017 in a tertiary family medicine clinic. The study sample consisted of individuals aged 18 years and over who applied to the outpatient clinic for complaints of fatigue for at least 1 month. Voluntary individuals who meet the inclusion criteria were informed about the study. A questionnaire assessing sociodemographic characteristics and fatigue perception, Fatigue Severity Scale (FSS) and Checklist Individual Strength (CIS) were applied to voluntary participants. Patient records from the outpatient clinic regarding this complaint, including history, physical 
examination and laboratory findings, were also included in the study. A total of 116 patients were included in the study.

Participants' fatigue perceptions were assessed by a structured form. It aims to identify what participants mean by fatigue and what the complaints of fatigue contain. There are 24 expressions in this form and participants answered these expressions in the form of yes or no. This form was generated by researchers with a preliminary study in March 2016.The patients who was referred to family medicine outpatient clinic with complaint of fatigue $(n=20)$ was asked "what do you mean when you say fatigue" and "what does your complaint contain" as open-ended. When the answers from the participants were compiled, 24 different fatigue perceptions were detected. These expressions were used to create the questionnaire.

The FSS is a questionnaire that measures the effect of fatigue on functionality. Kupp and colleagues have developed to facilitate research and treatment of patients with Multiple Sclerosis and Systemic Lupus Erythematosus ${ }^{16}$. The validity and reliability studies for Turkish population were made by Armutlu et al. in 2007, Gencay-Can and Can in 2012 and Öztürk et al. in 2017. The Turkish version was found valid and reliable ${ }^{17-19}$. The questionnaire consists of 9 expressions which question the fatigue situation in the last 1 week and a scale of 7 points is used for the answers.

CIS was designed by Vercoulen et al in 1994 to measure various aspects of fatigue and it is the most widely used questionnaire worldwide to assess chronic fatigue ${ }^{20}$. The validity and reliability study for Turkish population was made by Ergin and Yıldırım in 2012 and the Turkish version was found valid and reliable ${ }^{21}$. The questionnaire consists of 20 expressions measuring fatigue during the last 2 weeks and a scale of 7 points is used for answers. Patients' records including history, physical examination and laboratory results were also included in the study. According to this, depression scan was evaluated as positive if there are any of the symptoms of "depressed mood" or "interest - desire decreased, not enjoying life" in the story.

For the study, permission was obtained from Scientific Research Ethics Committee.

The data were analyzed by using the SPSS 18 (Statistical Package for the Social Sciences) package program. After descriptive statistics, Oneway ANOVA, Kruskall-Wallis test, Student's t test, Mann Whitney U test and Chi square test were used for comparing the variables. Statistical significance level was taken as $\mathrm{p}<0,05$.

\section{RESULTS}

The mean age of participants was $29.5 \pm 9.8$ years and $87.9 \%$ were women.

We asked patients "what do they mean by fatigue?" and "what fatigue complaints contain?". Tiredness $(96,6 \%)$, lack of energy $(91,4 \%)$ and sleeplessness (insomnia) somnolence - desire to sleep $(91,4 \%)$ were the most common answers (Figure 1).

Figure 1. Participants' fatigue perceptions

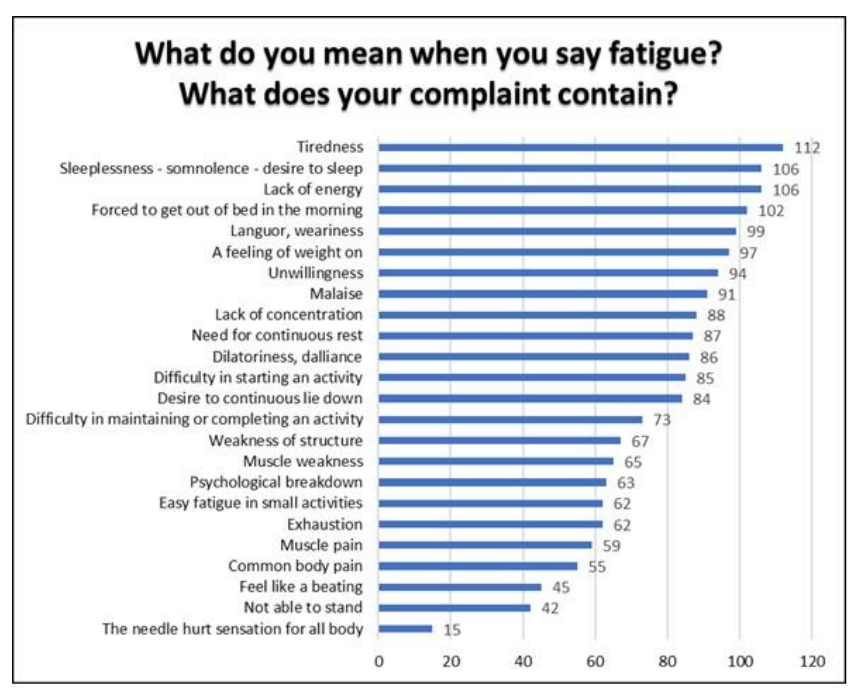

All participants filled out the FSS and CIS forms. The mean score of FSS was $4.5 \pm 1.4$ and the mean score of CIS was $91 \pm 20$. Perceptions with the highest scores of FSS and CIS scales are shown in Table 1.

When the patients' records are examined, $72.8 \%(n=83)$ of the participants stated that they had a sleeping problem and $69 \%(n=80)$ had a positive depression scan (Table 2).

At least one physical examination finding was found in $34.5 \%$ of the patients and at least one laboratory finding was found in $93.1 \%$ of the patients. While the most common signs of positive tender points that can be detected on physical examination (19.4\%) the most common laboratory finding was vitamin D deficiency (84.5\%). Other physical examination and laboratory findings and scale scores are shown in Table 3 and Table 4.

The relation of the fatigue perceptions to possible etiologic factors was examined (Figure 2). 
Table 1: Fatigue perceptions with the highest scale scores

\begin{tabular}{|l|c|c|c|c|}
\hline & FSS score & p value & CIS score & p value \\
\hline $\begin{array}{l}\text { The needle hurt sensation for all body } \\
\text { Yes }\end{array}$ & $\begin{array}{r}5,3 \pm 1,3 \\
4,4 \pm 1,4\end{array}$ & $\mathbf{0 , 0 2 4}$ & $\begin{array}{c}100 \pm 20 \\
90 \pm 19\end{array}$ & 0,064 \\
No & & & & \\
\hline $\begin{array}{l}\text { Easy fatigue in small activities } \\
\text { Yes }\end{array}$ & $5,2 \pm 1,3$ & $\mathbf{0 , 0 0 0}$ & $98 \pm 16$ & $\mathbf{0 , 0 0 0}$ \\
No & $3,7 \pm 1,2$ & & $82 \pm 20$ & \\
\hline $\begin{array}{l}\text { Psychological breakdown } \\
\text { Yes }\end{array}$ & $5,2 \pm 1,1$ & $\mathbf{0 , 0 0 0}$ & $99 \pm 18$ & $\mathbf{0 , 0 0 0}$ \\
No & $3,8 \pm 1,4$ & & $82 \pm 17$ & \\
\hline Feel like a beating & & & & \\
Yes & $5,1 \pm 1,2$ & $\mathbf{0 , 0 0 0}$ & $99 \pm 17$ & $\mathbf{0 , 0 0 1}$ \\
No & $4,1 \pm 1,5$ & & $86 \pm 19$ & \\
\hline
\end{tabular}

Table 2: Patients' history

\begin{tabular}{|l|c|c|c|c|c|c|}
\hline & $\mathbf{\%}$ & $\mathbf{N}$ & FSS score & p value & CIS score & p value \\
\hline $\begin{array}{l}\text { Report a sleeping problem } \\
\quad \text { Yes }\end{array}$ & 72,8 & 83 & $4,7 \pm 1,4$ & 0,080 & $93 \pm 18$ & 0,136 \\
$\quad$ No & 27,2 & 31 & $4,1 \pm 1,6$ & & $87 \pm 20$ & \\
\hline $\begin{array}{l}\text { Positive depression scan } \\
\text { Yes }\end{array}$ & 69 & 80 & $4,9 \pm 1,3$ & $\mathbf{0 , 0 0 0}$ & $96 \pm 18$ & $\mathbf{0 , 0 0 0}$ \\
$\quad$ No & 31 & 36 & $3,7 \pm 1,5$ & & $79 \pm 17$ & \\
\hline
\end{tabular}

Table 3: Physical examination

\begin{tabular}{|l|c|c|c|c|c|c|}
\hline & $\mathbf{\%}$ & $\mathbf{n}$ & FSS score & p value & CIS score & p value \\
\hline $\begin{array}{l}\text { Positive tender points } \\
\text { Yes }\end{array}$ & 19,4 & 20 & $4,9 \pm 1,2$ & 0,196 & $98 \pm 19$ & 0,091 \\
$\quad$ No & 80,6 & 83 & $4,4 \pm 1,5$ & & $90 \pm 19$ & \\
\hline $\begin{array}{l}\text { Pharynx pathology } \\
\text { Yes }\end{array}$ & 12,7 & 13 & $5,2 \pm 1,1$ & 0,082 & $95 \pm 15$ & 0,486 \\
$\quad$ No & 87,3 & 89 & $4,4 \pm 1,4$ & & $91 \pm 20$ & \\
\hline $\begin{array}{l}\text { Lymphadenopathy } \\
\text { Yes }\end{array}$ & 5,9 & 6 & $4,1 \pm 1,0$ & 0,411 & $87 \pm 10$ & 0,576 \\
$\quad$ No & 94,1 & 96 & $4,6 \pm 1,4$ & & $92 \pm 20$ & \\
\hline $\begin{array}{l}\text { Goiter } \\
\text { Yes }\end{array}$ & 4,9 & 5 & $4,5 \pm 1,0$ & 0,958 & $77 \pm 14$ & 0,076 \\
$\quad$ No & 95,1 & 97 & $4,5 \pm 1,4$ & & $92 \pm 19$ & \\
\hline $\begin{array}{l}\text { Arrhythmia } \\
\text { Yes }\end{array}$ & 2 & 2 & $4,2 \pm 0,2$ & 0,808 & $75 \pm 16$ & 0,224 \\
No & 98 & 100 & $4,5 \pm 1,4$ & & $92 \pm 20$ & \\
\hline
\end{tabular}

\section{DISCUSSION}

In our study, the fatigue perception of the patients who applied to the university family medicine outpatient clinic with the complaint of fatigue as the main symptom was evaluated. Expressions that is indicated within the scope of fatigue by almost all patients were tiredness, lack of energy and sleeplessness - somnolence - desire to sleep.

It has been seen that patients can evaluate very different situations such as "psychological breakdown" or "muscle pain" within the complaints of fatigue. This was similar to the study published by Chaudhuri et al. in 2004, which states that fatigue perception is subjective, and that there is no definite description due to the relationship between the idea of fatigue and the clinically relevant fatigue symptom $^{22}$. In other studies fatigue has been shown to be a complex phenomenon ${ }^{23}$, which is expressed as a subjective, unpleasant symptom involving body feelings ranging from tiredness to exhaustion ${ }^{24}$. The severity of fatigue increased when there were more rarely expressed perceptions in our study. For example, those with the lowest frequency of "the needle hurt sensation for all body" perception was the most severe. 
Nevertheless, it was observed that the measurement of these fatigue scores did not benefit clinically.

Previous studies have shown that female gender is higher $(62-76 \%)$ among patients with complaints of fatigue 4,25 . In our study, the female gender ratio was similarly found higher $(87.9 \%)$. The fact that fatigue is seen more in women may be due to differences in health perceptions as well as concentration of daily psychosocial burden on women. The hormonal fluctuations in the cycle may also make this explicit.

In our study, three out of four patients reported sleeping problems and in these the score of severity was higher. This is consistent with previous studies showing that fatigue is associated with subjective sleep quality ${ }^{26,27}$. The high rate of sleep problems in patients may be due to the direct cause of sleep problems in physiological fatigue. In addition, it may have been effective for people to express some situations such as sleeplessness, insomnia and somnolence as fatigue. In a review published in 2013, patients were told that the terms sleepiness and fatigue could be used interchangeably ${ }^{28}$. In our study, two of the perceptions associated with the sleeping problem are "sleeplessness (insomnia) somnolence - desire to sleep" and "forced to get out of bed in the morning", which reinforces this argument. In this case, it is important to question sleep problems in detail in a patient with a complaint of fatigue.

Previous studies have shown that depression is more common in those with fatigue ${ }^{29-31}$ and fatigue is more severe in those with depression ${ }^{27,32,33}$. The depression rate ranges from 19 to $60 \%$ for those with fatigue ${ }^{34-39}$. In our study, approximately two-thirds of patients were shown to be at risk of depression. The mean scores of these participants on both the FSS and the CIS survey were significantly higher than the other group. Depression may be the primary effect of fatigue etiology. However, it is also not forgotten that depression may emerge as a secondary in people suffering from longlasting fatigue due to somatic reasons. This is supported by the fact that most of the fatigue perceptions in which the rate of depression is high are also related to the physical examination or laboratory findings at the same time. As a result, it would be wise to look for signs of depression in a patient with a complaint of fatigue. However, it should not be forgotten that the presence of depression in the patient cannot clearly exclude another underlying disease and care should be taken for the necessary physical examination and laboratory investigations.

The most common laboratory finding in the participants was vitamin D deficiency. Approximately $80 \%$ of patients had serum vitamin D levels below $20 \mathrm{ng} / \mathrm{ml}$. In a study conducted in 2014 with patients complaining of fatigue, the prevalence of low vitamin D was reported as $77.2 \%{ }^{40}$. Similarly, in another study conducted in 2016, the proportion of vitamin D deficiency was found to be $64 \%$ in fatigue patients and vitamin D therapy has shown a marked improvement in fatigue ${ }^{41}$. In all these cases, the measurement of the level of vitamin D in a patient presenting with fatigue will be helpful.

Table 4: Laboratory findings

\begin{tabular}{|c|c|c|c|c|c|c|}
\hline & $\%$ & $\mathbf{n}$ & FSS score & p value & CIS score & p value \\
\hline $\begin{array}{l}\text { Anemia } \\
\text { Yes (Hemoglobin }<12 \mathrm{~g} / \mathrm{dl} \text { ) } \\
\text { No }(\text { Hemoglobin } \geq 12 \mathrm{~g} / \mathrm{dl})\end{array}$ & $\begin{array}{l}12,9 \\
87,1 \\
\end{array}$ & $\begin{array}{c}15 \\
101 \\
\end{array}$ & $\begin{array}{l}5,3 \pm 1,0 \\
4,4 \pm 1,5 \\
\end{array}$ & 0,022 & $\begin{array}{l}94 \pm 17 \\
90 \pm 20 \\
\end{array}$ & 0,521 \\
\hline $\begin{array}{l}\text { TSH } \\
<0,5 \mathrm{uIU} / \mathrm{ml} \text { hyperthyroid } \\
0,5-4 \mathrm{uIU} / \mathrm{ml} \text { euthyroid } \\
4>\mathrm{uIU} / \mathrm{ml} \text { hypothyroid }\end{array}$ & $\begin{array}{c}1,8 \\
91,1 \\
7,1 \\
\end{array}$ & $\begin{array}{c}2 \\
102 \\
8\end{array}$ & $\begin{array}{l}3,9 \pm 2,0 \\
4,5 \pm 3,4 \\
3,0 \pm 2,8\end{array}$ & 0,181 & $\begin{array}{l}83 \pm 23 \\
91 \pm 20 \\
84 \pm 3\end{array}$ & 0,475 \\
\hline \begin{tabular}{|c|} 
Iron deficiency* \\
Yes \\
No \\
\end{tabular} & $\begin{array}{l}36 \\
64 \\
\end{array}$ & $\begin{array}{l}40 \\
71 \\
\end{array}$ & $\begin{array}{l}4,8 \pm 1,3 \\
4,4 \pm 1,5 \\
\end{array}$ & 0,262 & $\begin{array}{l}93 \pm 19 \\
91 \pm 19 \\
\end{array}$ & 0,451 \\
\hline \begin{tabular}{|} 
Vitamin B12 deficiency \\
Yes $(<200 \mathrm{pg} / \mathrm{ml})$ \\
No $(\geq 200 \mathrm{pg} / \mathrm{ml})$ \\
\end{tabular} & $\begin{array}{l}30,4 \\
69,6 \\
\end{array}$ & $\begin{array}{l}35 \\
80 \\
\end{array}$ & $\begin{array}{l}4,5 \pm 1,1 \\
4,5 \pm 1,6 \\
\end{array}$ & 0,829 & $\begin{array}{l}89 \pm 19 \\
92 \pm 20 \\
\end{array}$ & 0,462 \\
\hline \begin{tabular}{|c|} 
Vitamin D deficiency \\
Yes $(<20 \mathrm{ng} / \mathrm{ml})$ \\
No $(\geq 20 \mathrm{ng} / \mathrm{ml})$ \\
\end{tabular} & $\begin{array}{l}84,5 \\
15,5 \\
\end{array}$ & $\begin{array}{l}82 \\
15 \\
\end{array}$ & $\begin{array}{l}4,6 \pm 1,4 \\
3,8 \pm 1,6 \\
\end{array}$ & 0,055 & $\begin{array}{l}92 \pm 19 \\
86 \pm 25 \\
\end{array}$ & 0,290 \\
\hline $\begin{array}{l}\text { Fasting blood glucose } \\
\text { High }(\geq 100 \mathrm{mg} / \mathrm{dl}) \\
\text { Normal }(<100 \mathrm{mg} / \mathrm{dl}) \\
\end{array}$ & $\begin{array}{r}5,5 \\
94,5 \\
\end{array}$ & $\begin{array}{c}6 \\
103 \\
\end{array}$ & $\begin{array}{l}3,1 \pm 1,6 \\
4,6 \pm 1,4 \\
\end{array}$ & 0,010 & $\begin{array}{c}96 \pm 9 \\
91 \pm 20 \\
\end{array}$ & 0,598 \\
\hline $\begin{array}{l}\text { Sedimentation height } \\
\text { Yes } \\
\text { No } \\
\end{array}$ & $\begin{array}{c}4,3 \\
95,7\end{array}$ & $\begin{array}{c}4 \\
88 \\
\end{array}$ & $\begin{array}{l}5,6 \pm 1,4 \\
4,6 \pm 1,4\end{array}$ & 0,142 & $\begin{array}{l}99 \pm 15 \\
92 \pm 19\end{array}$ & 0,517 \\
\hline
\end{tabular}

*Serum ferritin levels were $\leq 23.9 \mathrm{ng} / \mathrm{ml}$ for men and $\leq 11 \mathrm{ng} / \mathrm{ml}$ for women 
The most important limitation of this study is that participants gathered from patients who apply to a tertiary health care facility. In a previous study, fatigue characteristics of patients who applied to primary and tertiary health care facilities were found to differ ${ }^{42}$. A significant majority of the patients referred to the study center were students and health workers. This has lowered the mean age, raised the socio-economic level and has made it more difficult to attribute the results to the general population. Therefore, field studies to be carried out about fatigue perception will provide more meaningful findings.

Figure 2. Patients' fatigue perceptions and related etiologic factors

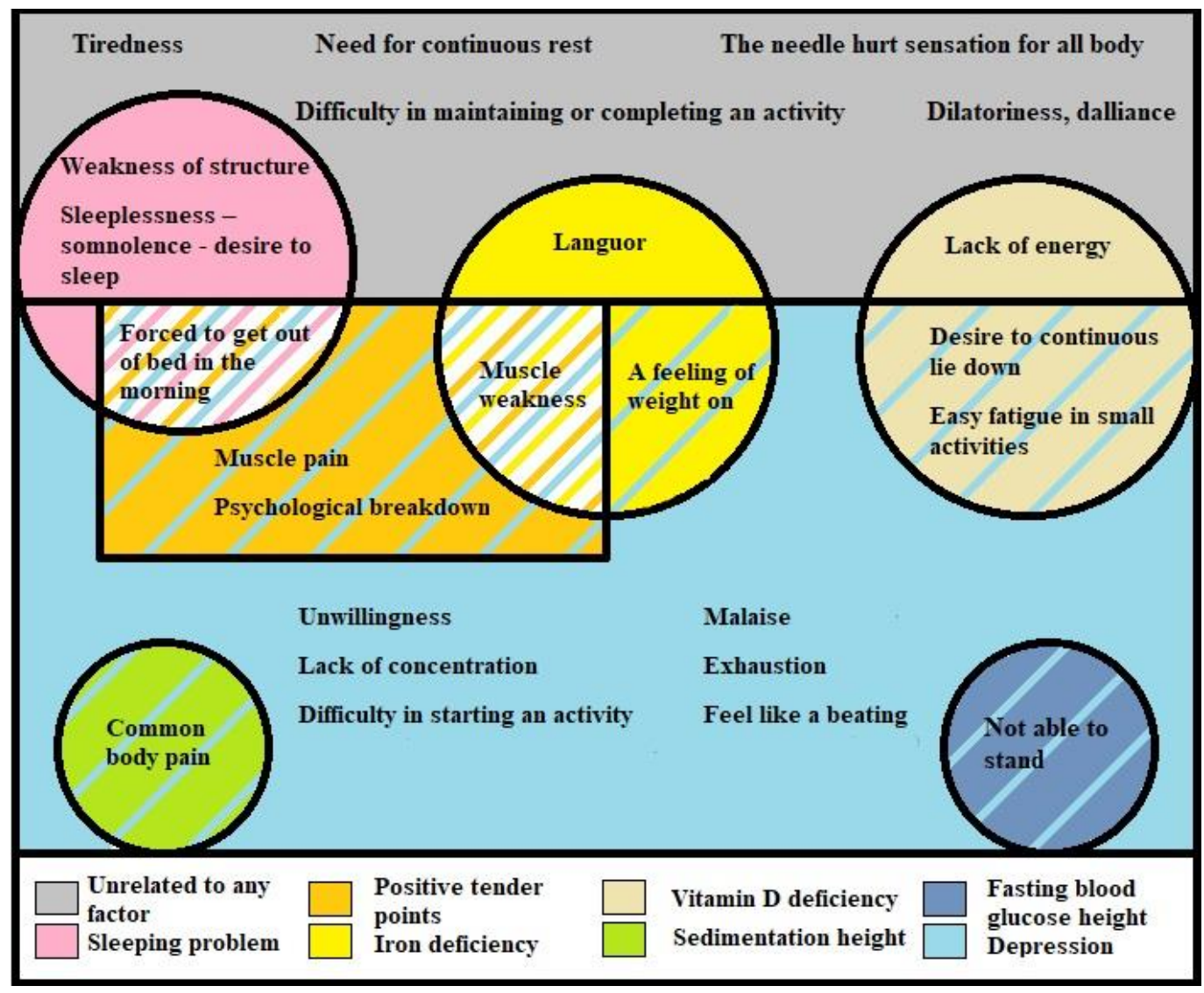

This is the first study to question the content of fatigue and what the patients mean from fatigue and to evaluate the effect of this on patient management. As a result of this study, it has been shown that this content is at least as important as other features of fatigue.

Family physicians should not regard the symptom "fatigue" as a single pattern. They should investigate its content and try to understand the patient. This is important for both facilitating patient management and avoiding unnecessary health expenditures.

This study presented as a poster paper on September 28, 2017 at the 11th Family Medicine Autumn School.
Declaration of Conflicting Interests: The authors declare that they have no conflict of interest.

Financial Disclosure: No financial support was received.

\section{REFERENCES}

1. Kenter EG, Okkes IM, Oskam SK, Lamberts H. Tiredness in Dutch family practice. Data on patients complaining of and/or diagnosed with "tiredness". Fam Pract. 2003;20:434-40.

2. Andrea H, Kant IJ, Beurskens AJHM, Metsemakers JFM, van Schayck CP. Associations between fatigue attributions and fatigue, health, and psychosocial work characteristics: a study among employees visiting a 
physician with fatigue. Occup Environ Med. 2003;60:99-104.

3. Sharpe M, Wilks D. Fatigue. BMJ. 2002;325:480-3.

4. Cullen W, Kearney Y, Bury G. Prevalence of fatigue in general practice. Ir J Med Sci. 2002;171:10-2.

5. Kenter EG, Okkes IM. [Patients with fatigue in family practice: prevalence and treatment]. Ned Tijdschr Geneeskd. 1999;143:796-801.

6. Mengel M, Schwiebert P. Family Medicine: Ambulatory Care and Prevention. McGraw-Hill; 2013;168-73 p.

7. Bates DW, Schmitt W, Buchwald D, Ware NC, Lee J, Thoyer E, et al. Prevalence of fatigue and chronic fatigue syndrome in a primary care practice. Arch Intern Med. 1993;153:2759-65.

8. Fosnocht KM, Ende J. Approach to the adult patient with fatigue 2017 [updated 13.06.2016. Available from: https://www.uptodate.com/contents/approach-tothe-adult-patient-with-

fatigue? source=search_result\&search=fatigue\&selected Title=1 150.

9. Holley AB. The Evaluation and Management of Fatigue 2015 [updated 14.10.2015. Available from: http://www.medscape.com/viewarticle/852370.

10. Gregory P, Edsell M. Fatigue and the Anaesthetist. Continuing Education in Anaesthesia, Critical Care \& Pain. 2014;14:18-22.

11. Ricci JA, Chee E, Lorandeau AL, Berger J. Fatigue in the U.S. workforce: prevalence and implications for lost productive work time. J Occup Environ Med. 2007;49:110.

12. Murtagh J. Fatigue--a general diagnostic approach. Aust Fam Physician. 2003;32:873-6.

13. Janssen N, Kant IJ, Swaen GMH, Janssen PPM, Schroer CAP. Fatigue as a predictor of sickness absence: results from the Maastricht cohort study on fatigue at work. Occup Environ Med. 2003;60:71-6.

14. Nelson E, Kirk J, McHugo G, Douglass R, Ohler J, Wasson J, et al. Chief complaint fatigue: a longitudinal study from the patient's perspective. Fam Pract Res J. 1987;6:175-88.

15. Deale A, Wessely S. Patients' perceptions of medical care in chronic fatigue syndrome. Soc Sci Med. 2001;52:1859-64.

16. Krupp LB, Larocca NG, Muirnash J, Steinberg AD. The Fatigue Severity Scale - Application to Patients with Multiple-Sclerosis and Systemic Lupus-Erythematosus. Arch Neurol-Chicago. 1989;46:1121-3.

17. Armutlu K, Korkmaz NC, Keser I, Sumbuloglu V, Akbiyik DI, Guney Z, et al. The validity and reliability of the Fatigue Severity Scale in Turkish multiple sclerosis patients. Int J Rehabil Res. 2007;30:81-5.
18. Gencay-Can A, Can SS. Validation of the Turkish version of the fatigue severity scale in patients with fibromyalgia. Rheumatol Int. 2012;32:27-31.

19. Ozturk EA, Gonenli Kocer B, Gundogdu I, Umay E, Cakci FA. Reliability and validity study of a Turkish version of the fatigue severity scale in Parkinson's disease patients. Int J Rehabil Res. 2017;40:185-90.

20. Vercoulen JHMM, Swanink CMA, Fennis JFM, Galama JMD, Vandermeer JWM, Bleijenberg G. Dimensional Assessment of Chronic Fatigue Syndrome. Journal of Psychosomatic Research. 1994;38:383-92.

21. Ergin G, Yildirim Y. A validity and reliability study of the Turkish Checklist Individual Strength (CIS) questionnaire in musculoskeletal physical therapy patients. Physiotherapy theory and practice. 2012;28:624-32.

22. Chaudhuri A, Behan PO. Fatigue in neurological disorders. Lancet. 2004;363:978-88.

23. Ream E, Richardson A. Fatigue in patients with cancer and chronic obstructive airways disease: a phenomenological enquiry. International journal of nursing studies. 1997;34:44-53.

24. Ream E, Richardson A. Fatigue: a concept analysis. International journal of nursing studies. 1996;33:51929.

25. Kenter E, Okkes I, Oskam S, Lamberts H. Once tired, always tired? Limitations in function over time of tired patients in Dutch general practice. The European journal of general practice. 2007;13:67-74.

26. Nijrolder I, van der Windt D, van der Horst $H$. Prediction of outcome in patients presenting with fatigue in primary care. Br J Gen Pract. 2009;5:e101-9.

27. Lavidor M, Weller A, Babkoff H. How sleep is related to fatigue. British Journal of Health Psychology. 2003;8:95-105.

28. Hirshkowitz M. Fatigue, Sleepiness, and Safety: Definitions, Assessment, Methodology. Sleep Medicine Clinics. 2013;8:183-9.

29. Wong WS, Fielding R. Prevalence of chronic fatigue among Chinese adults in Hong Kong: A populationbased study. J Affect Disorders. 2010;127:248-56.

30. Walker EA, Katon WJ, Jemelka RP. Psychiatric disorders and medical care utilization among people in the general population who report fatigue. J Gen Intern Med. 1993;8:436-40.

31. Cathebras PJ, Robbins JM, Kirmayer LJ, Hayton BC. Fatigue in primary care: prevalence, psychiatric comorbidity, illness behavior, and outcome. J Gen Intern Med. 1992;7:276-86.

32. Daniels L, Oerlemans S, Krol A, Creutzberg C, Van de Poll-Franse L. Chronic fatigue in Hodgkin lymphoma 
survivors and associations with anxiety, depression and comorbidity. Brit J Cancer. 2014;110:868.

33. Lim WJ, Hong S, Nelesen R, Dimsdale JE. The association fo obesity, cytokine levels, and depressive symptoms with diverse measures of fatigue in healthy subjects. Archives of Internal Medicine. 2005;165:9105.

34. Stadje R, Dornieden K, Baum E, Becker A, Biroga T, Bosner S, et al. The differential diagnosis of tiredness: a systematic review. BMC Fam Pract. 2016;17:147.

35. Nijrolder I, van der Windt D, de Vries $\mathrm{H}$, van der Horst $\mathrm{H}$. Diagnoses during follow-up of patients presenting with fatigue in primary care. Can Med Assoc J. 2009;181:683-7.

36. Bultmann U, Kant I, Kasl SV, Beurskens AJ, van den Brandt PA. Fatigue and psychological distress in the working population: psychometrics, prevalence, and correlates. J Psychosom Res. 2002;52:445-52.

37. Manu P, Lane TJ, Matthews DA. Chronic fatigue and chronic fatigue syndrome: clinical epidemiology and aetiological classification. Ciba Found Symp. 1993;173:23-31; discussion -42.
38. Gerber PD, Barrett JE, Barrett JA, Oxman TE, Manheimer E, Smith $\mathrm{R}$, et al. The relationship of presenting physical complaints to depressive symptoms in primary care patients. J Gen Intern Med. 1992;7:170-3.

39. Manu P, Matthews DA, Lane TJ. The mental health of patients with a chief complaint of chronic fatigue. A prospective evaluation and follow-up. Arch Intern Med. 1988;148:2213-7.

40. Roy S, Sherman A, Monari-Sparks MJ, Schweiker O, Hunter K. Correction of Low Vitamin D Improves Fatigue: Effect of Correction of Low Vitamin D in Fatigue Study (EViDiF Study). N Am J Med Sci. 2014;6:396-402.

41. Nowak A, Boesch L, Andres E, Battegay E, Hornemann $\mathrm{T}$, Schmid C, et al. Effect of vitamin D3 on self-perceived fatigue: A double-blind randomized placebo-controlled trial. Medicine (Baltimore). 2016;95:e5353.

42. Euba R, Chalder T, Deale A, Wessely S. A comparison of the characteristics of chronic fatigue syndrome in primary and tertiary care. The British Journal of Psychiatry. 1996;168:121-6. 